\title{
DETERMINANTS OF TOURISM ATTRACTIVENESS IN THE NATIONAL PARKS OF BRAZIL
}

\author{
Ernesto Viveiros de Castro ${ }^{1}$, Thiago Beraldo Souza ${ }^{2,4} *$ and Brijesh Thapa ${ }^{3}$ \\ * Corresponding author: thiagoberaldo@yahoo.com.br \\ ${ }^{1}$ Tijuca National Park, Rio de Janeiro, Brazil \\ ${ }^{2}$ Chico Mendes Institute for Biodiversity Conservation, Brasília, Brazil \\ ${ }^{3}$ Department of Tourism, Recreation \& Sport Management, University of Florida, USA \\ ${ }^{4}$ School of Natural Resources and Environment, University of Florida, USA
}

\begin{abstract}
Understanding the determinant attributes that affect the tourism attractiveness of National Parks is a strategic planning tool for protected areas. This exploratory study assessed the relative importance of various internal and external park characteristics on visitation numbers in Brazil. Data were collected from several sources: 28 park managers, internal park documents, government databases and various websites. The study used correlation and regression analysis. Results demonstrated that tourism attractiveness in the national parks can be predicted through reputation, recreation facilities, attractions in the region and population density. Results show that both internal park attributes and external setting characteristics are considered by visitors. The results have practical utility and can be used to improve investments efficacy among the parks that already receive visitors, as well as serve to evaluate the tourism attractiveness for new parks. Also, findings are useful for the communities and small businesses located in the adjacent areas, since adequate prediction of visitor demand provides support for tourism activities.
\end{abstract}

Key words: Ecotourism, outdoor recreation, tourism attractiveness, national parks, Brazil

\section{INTRODUCTION}

Protected areas are globally considered as a key strategy for conservation of natural environments and species. Among the various types of protected areas, IUCN category II protected areas (e.g. national parks) have the objective to provide access for tourism and recreation. The promotion of tourism helps to raise societal awareness and increases support for biodiversity conservation. Category II, national parks offer numerous recreational settings that attract visitors, and the public use reinforces support for the creation and maintenance of such areas (Eagles \& McCool, 2002; Weiler et al., 2013). In addition, visitor use management also creates alternative employment and income for local communities that are adjacent to parks, and is dependent on visitor flows and associated expenditures in the area (Emerton et al., 2006; Neuvonen et al., 2010; Thapa, 2013). Hence, the relationship of parks' attributes and regional characteristics along with visitation volume are essential for planning and management goals (Puustinen et al., 2009), given the local linkages as well as the need to optimize visitor experiences (Mulholland \& Eagles, 2002).
Visitor demand and associated park choices have been extensively examined, and correlations with internal park features and related quality have been identified (Manning, 2011). However, external characteristics such as access, accommodations, and available services outside the park have also been noted as factors that influence visitation (Neuvonen et al., 2010; Puustinen et al., 2009). In fact, a site is considered by visitors within the larger context of a destination and is evaluated based on its tourism attractiveness (Formica \& Uysal, 2006). The concept has been widely used to classify destinations, and has also been applied within the context of protected areas (Choi, 2012; Deng et al., 2002; Lee et al., 2010). Tourism attractiveness (Gearing et al., 1974) has been utilized to understand visitors' decision making processes and is dependent on availability of attractions and associated perceived importance (Formica \& Uysal, 2006). Moreover, tourism attractiveness has been segmented into two broad categories: primary and secondary attributes. Primary attributes are innate to a destination and are related to its natural beauty and heritage, while secondary attributes are related to tourist infrastructure (Laws, 


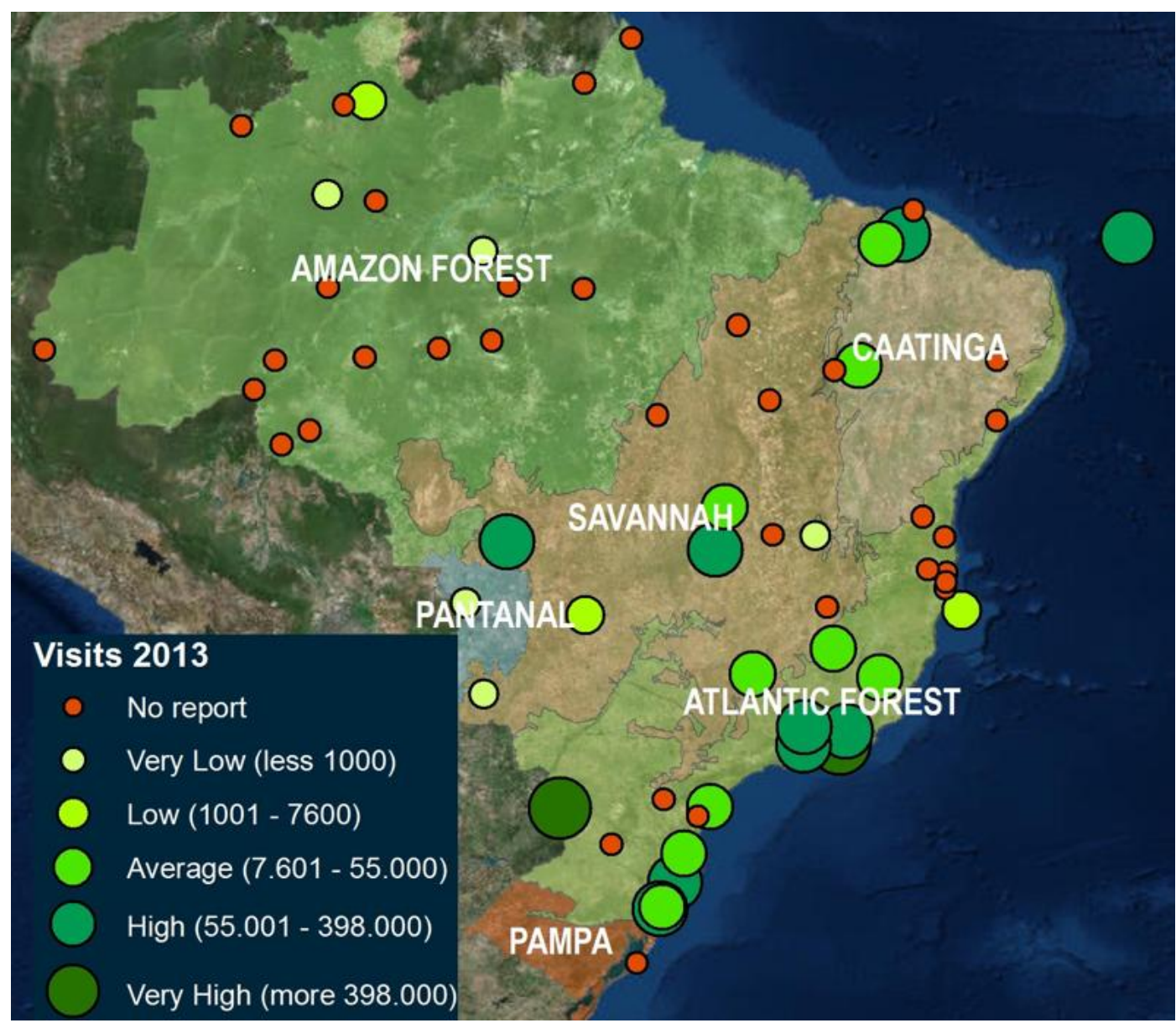

Figure 1: Visitation in national parks of Brazil in 2013

1995). The secondary attributes include accessibility, lodging facilities, food, services and activities. In addition, these have been further subdivided into internal and external attributes. In protected areas, internal are those that exist within, such as management policy, infrastructure and services. External are related to infrastructure and concentration of attractions around the protected areas (Puustinen et al., 2009). The determination of the relative importance of each of these factors is the most critical aspect for development of a destination (Hu \& Ritchie, 1993; Neuvonen et al., 2010).

Most research has been based on qualitative analyses via expert panels (Deng et al., 2002; Lee et al., 2010) or quantitative tourist surveys (Choi, 2012; Thapa et al., 2011). While both approaches have their merits, limitations are evident given the subjectivity and ability to analyze multiple destinations, especially remote regions where most protected areas are located. Moreover, research has largely been focused on either a demand (i.e., tourists) or supply perspective (i.e., internal park attributes) with limited integration of both to understand visitation (Neuvonen et al., 2010). While demand-based research has been dominant, the supply side analysis has also emerged to further examine the relationships between park characteristics and visitation. An analysis by Puustinen et al. (2009) of 35 Finnish national parks acknowledged that higher volume of visitation was associated with natural characteristics as well as the availability of recreational facilities inside and tourism services outside the parks. Furthermore, based on the same sample, Neuvonen et al. (2010) examined the visitation numbers in relationship to the parks' internal and external attributes and identified that recreational opportunities, trails, diversity of biotopes, and a park's age increased volume of visits from all around the country. However, a park's location was only significant in southern Finland. Overall, both studies provide an improved approach to the examination of park visitation which has demonstrated utility for planning, policy and management decisions.

Using a similar framework, this exploratory study was to further build and assess the relative importance of various internal and external park characteristics with respect to visitation numbers in the national parks of Brazil. The federal system of protected areas encompasses 76 million hectares divided into 320 units, of which 71 are designated as national parks (see Figure 1). Based on the scale and units, the national parks receive a comparatively small volume of visitors: 6.5 million in 2014 which is skewed towards two parks (Tijuca and Iguaçu) that have an international brand image (ICMBio, 2014). The lack of visitor influx to other 
Table 1: National Parks included in this study (ICMBio, 2014)

National Park Name

Year of

establishment
Area (ha.) Ecoregion 2013 Visits

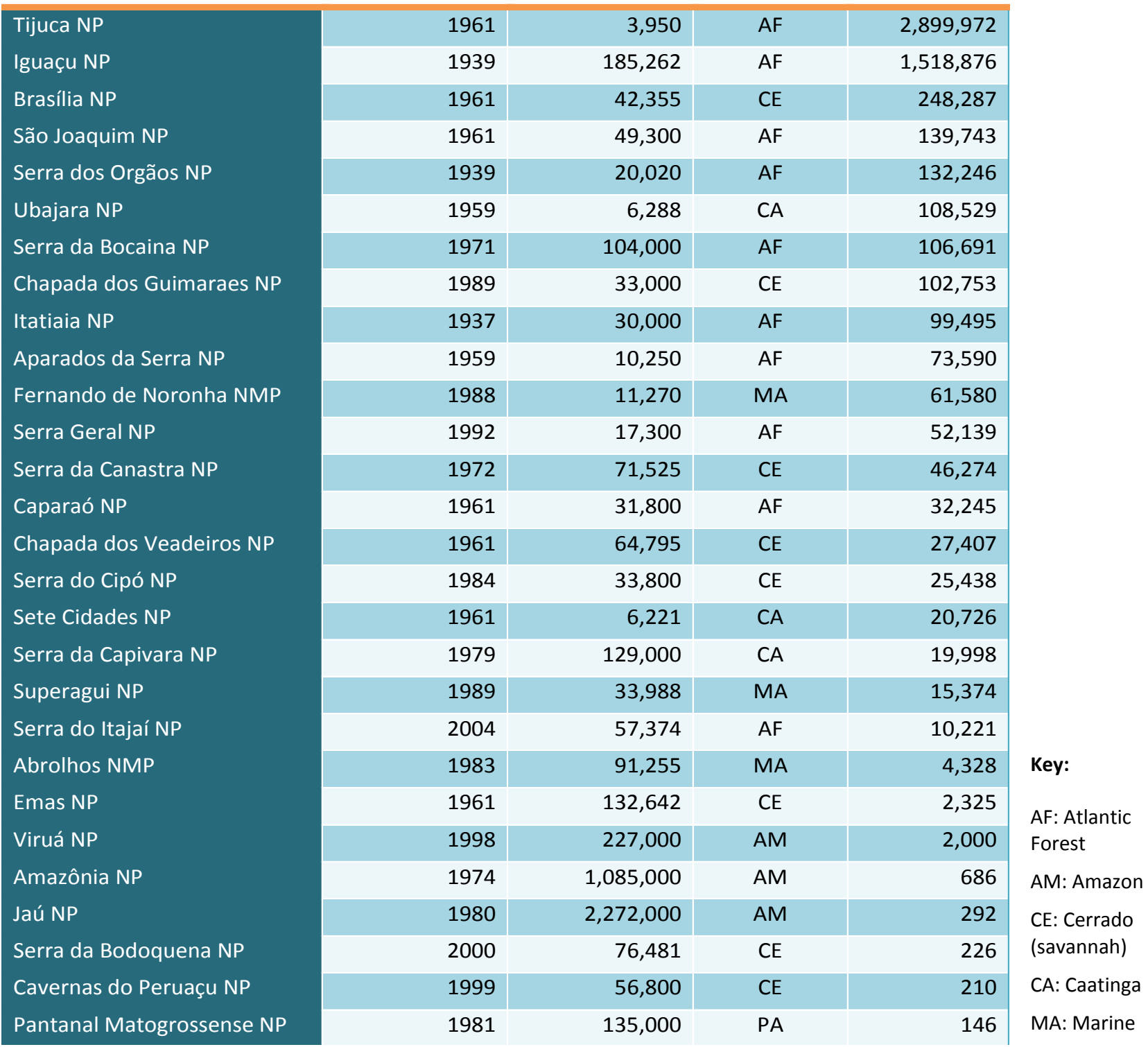

parks may be the result of various issues. For example, the lack of opportunities and infrastructure development has been evident. One possible cause is due to the Protected Areas Agency's longstanding viewpoint towards tourism. For the past 30 years, tourism has been perceived as an agent of change, such as exotic plants or fire which has justified strong restrictive policies for outdoor recreation in the national parks of Brazil (Zimmerman, 2006). Furthermore, the combination of lack of societal support and budgetary constraints has also created a vicious cycle which has hindered the growth of visitation and support for protected areas. In order to assist decision-makers and park managers with respect to resources allocation, investment priorities, and sustainability of protected areas, the objective of this study is to contribute to an enhanced understanding based on factors that influence visitor flows to the national parks in Brazil.

\section{METHODS}

Sample: ICMBio (Chico Mendes Institute for Biodiversity Conservation) is the federal authority under the Ministry of Environment that is responsible for the management of Brazilian Federal Protected Areas. Among the national park units $(\mathrm{N}=71)$, there are only a few that are prepared for tourism, while others are minimally equipped, and most do not control access nor have entry fees. Based on the General Coordination of Public Use and Business, this study only included national parks $(\mathrm{N}=36)$ that had registered visitors in 2013 based on paid user fees (see Table 1). 
Table 2: Operationalization of variables

\begin{tabular}{|c|c|c|}
\hline \multicolumn{3}{|r|}{ Dependent variable } \\
\hline \multirow[t]{2}{*}{ Visits } & & Number of visitors in each park in 2013 (Log) \\
\hline & & Independent variables - Internal Setting \\
\hline \multirow[t]{2}{*}{$\begin{array}{l}\text { Physical } \\
\text { Attributes }\end{array}$} & Reputation & $\begin{array}{l}\text { Number of citations based on a Google search of the park's name and most } \\
\text { important attraction in Portuguese and English (Log). }\end{array}$ \\
\hline & Park Age & Number of years since the National Park designation. \\
\hline \multirow{6}{*}{$\begin{array}{l}\text { Social } \\
\text { Attributes } \\
\text { Managerial } \\
\text { Attributes }\end{array}$} & $\begin{array}{l}\text { Diversity of } \\
\text { Activities }\end{array}$ & $\begin{array}{l}\text { Number of recreation and sports activities offered (i.e., trekking, climbing, } \\
\text { diving, cycling etc.). }\end{array}$ \\
\hline & $\begin{array}{l}\text { Recreation } \\
\text { Facilities }\end{array}$ & Number of structures offered (i.e., lookouts, parking lots, visitor centre, etc.). \\
\hline & $\begin{array}{l}\text { Visitor } \\
\text { Services }\end{array}$ & $\begin{array}{l}\text { Number of services provided by the park or concessionaires (i.e., transport, } \\
\text { souvenirs, food etc.). }\end{array}$ \\
\hline & Planning Tools & $\begin{array}{l}\text { Number of management documents the park has produced and updated (i.e., } \\
\text { General Management Plan, Outdoor Recreation Plan, Interpretation Plan } \\
\text { etc.). }\end{array}$ \\
\hline & Land Tenure & Percentage of the park owned by the government. \\
\hline & & Independent variables - External Setting \\
\hline $\begin{array}{l}\text { Physical } \\
\text { Attributes }\end{array}$ & $\begin{array}{l}\text { Regional } \\
\text { Attractions }\end{array}$ & $\begin{array}{l}\text { Number of tourism attractions in the region based on a TripAdvisor web } \\
\text { search where the park is queried via the number of 'Things to Do' in the } \\
\text { park's adjacent municipalities (Log). }\end{array}$ \\
\hline \multirow{5}{*}{$\begin{array}{l}\text { Managerial } \\
\text { Attributes } \\
\text { Social } \\
\text { Attributes }\end{array}$} & $\begin{array}{l}\text { Hospitality } \\
\text { Establishments }\end{array}$ & $\begin{array}{l}\text { Number of lodging rooms and restaurants mentioned on Trip Advisor web } \\
\text { search for municipalities adjacent to the park (Log). }\end{array}$ \\
\hline & $\begin{array}{l}\text { Socioeconomic } \\
\text { Context }\end{array}$ & $\begin{array}{l}\text { Average Human Development Index - HDI of the municipalities adjacent to } \\
\text { the park. }\end{array}$ \\
\hline & $\begin{array}{l}\text { Population } \\
\text { Density }\end{array}$ & $\begin{array}{l}\text { Number of citizens living in adjacent municipalities included within a buffer } \\
\text { zone of } 100 \mathrm{~km} \text { around the park (Log). }\end{array}$ \\
\hline & Remoteness & $\begin{array}{l}\text { Travel time to the park from the nearest large city ( }>500,000 \text { people) added } \\
\text { to the time from closest national or international airport based on Google } \\
\text { Maps tools. For boat access, the park managers were requested to provide } \\
\text { the navigation hours ( } \mathrm{Log}) \text {. }\end{array}$ \\
\hline & $\begin{array}{l}\text { Local } \\
\text { Population }\end{array}$ & Population that live in the adjacent gateway municipalities of the park (Log). \\
\hline
\end{tabular}

Data collection: Data were collected from three different sources. First, primary data were collected from 28 park managers via an on-line survey during September 2014. Second, data were obtained from ICMBio internal documents (i.e., management reports). Third, secondary mediums such as government databases and various websites from the Internet were used. The use of the Web as a source of information within the tourism academic discipline has been found to be a reliable alternative as it is more practical and less costly than primary field data (Wood et al., 2013).

Operationalization of variables: Park visits were the dependent variable and were represented by the registered number of visitors in each national park [1]. For the independent variables, first, a comprehensive literature review was conducted prior to the development of the variables for the framework. Additional emphasis was given to the empirical studies on Finnish national parks (Neuvonen et al., 2010; Puustinen et al., 2009). A total of 13 independent variables were defined and operationalized. The identified variables were categorized based on the Recreation Opportunity
Spectrum (ROS) classification - Physical, Social, and Managerial (Clark \& Stankey, 1979). The 13 variables within the three ROS classifications (Physical, Social, and Managerial) were further segmented into two categories of settings - Internal and External to the park (see Table 2). All variables were discussed and approved via a focus group session with park managers in August 2014.

Internal setting: The variables within this setting were reflective of internal attributes of a park, such as natural beauty, diversity of recreation activities, park age and planning tools. The physical category is usually comprised of park attributes that include natural beauty and historical heritage. However, the perception of beauty or importance thereof is subjective and poses measurement challenges (Neuvonen et al., 2010; Puustinen et al., 2009). Hence, the study opted to use the park's reputation as a proxy and was objectively measured based on Google Citations [2]. Essentially, each park's name as well as its most important attraction was queried in English and Portuguese [3] during April 2015. A second variable, park age, was also included within this category. 
Table 3: Pearson' Correlation Coefficients

\begin{tabular}{|c|c|c|c|}
\hline ROS & \multicolumn{3}{|c|}{ Pearson' correlation } \\
\hline \multicolumn{4}{|c|}{ Internal Setting } \\
\hline \multirow[t]{2}{*}{ Physical Attributes } & Reputation & $0.749 * *$ & 0.000 \\
\hline & Park Age & $0.462^{*}$ & 0.013 \\
\hline Social Attributes & Diversity of Activities & $0.441^{*}$ & 0.019 \\
\hline \multirow{5}{*}{ Managerial Attributes } & Recreation Facilities & $0.610 * *$ & 0.001 \\
\hline & Visitor Services & $0.552 * *$ & 0.002 \\
\hline & Planning Tools & 0.062 & 0.754 \\
\hline & Land Tenure & -0.121 & 0.539 \\
\hline & External Sc & & \\
\hline \multirow{2}{*}{$\begin{array}{l}\text { Physical Attributes } \\
\text { Managerial Attributes }\end{array}$} & Regional Attractions & $0.613^{* *}$ & 0.001 \\
\hline & Hospitality Establishments & $0.601 * *$ & 0.001 \\
\hline \multirow[t]{4}{*}{ Social Attributes } & Socioeconomic Context & $0.570 * *$ & 0.002 \\
\hline & Population Density & $0.645^{* *}$ & 0.000 \\
\hline & Remoteness & $-0.707 * *$ & 0.000 \\
\hline & Local Population & 0.342 & 0.075 \\
\hline
\end{tabular}

The social category encompassed a variable that represented the diversity of recreation and sport activities located within the park (e.g., trekking, climbing, diving, etc.). The managerial category included variables that focused on recreation facilities (e.g., lookouts, parking lots, visitor centre) and visitor services (e.g., guides, concessionaires). In order to test ICMBio's historical assumption that visitation depends on secure land tenure and prior preparation of general management plans, variables such as planning tools (e.g., management documents, outdoor recreation plan) and land tenure (i.e., percentage of park ownership by the government) were also included.

External setting: The variables within this external setting were considered regional characteristics that could influence visitation, such as regional attractions, tourism infrastructure, socioeconomic context, and population density. More specifically, the physical category consisted of attractions in the park's region. Specific information was compiled from the TripAdvisor [4] website. The web link 'Things to do' was searched for information in regard to gateway communities/cities. Similarly, TripAdvisor was employed to compile information about tourism infrastructure such as accommodations and restaurants which were noted as hospitality establishments under the managerial category. The social category consisted of a park's gateway community population and density along with the socioeconomic context (i.e., average human development index - HDI). Information about the regions and population data were collected from georeferenced databases. Additionally, remoteness along

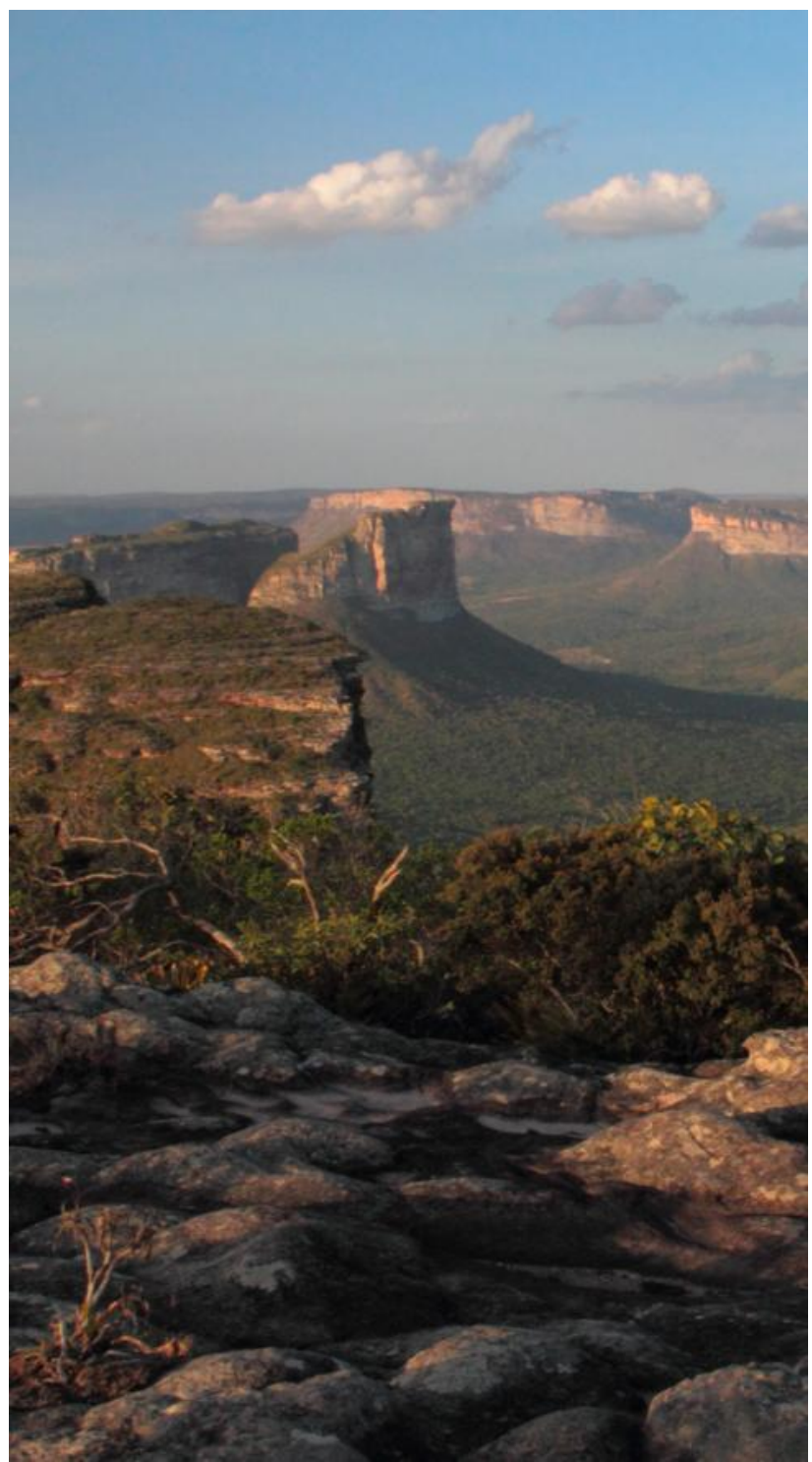

Chapada Diamantina National Park @ Ernesto V Castro 
Table 4: Summary of Multiple Regression Analysis

\begin{tabular}{|c|c|c|c|c|c|}
\hline Variable & & Partial $\mathrm{R}^{2}$ & B & \multicolumn{2}{|c|}{$p$-value } \\
\hline Intercept & & & & -1.397 & 0.214 \\
\hline Park Reputation & & 0.4942 & & 0.552 & 0.037 \\
\hline Recreational Facilities & & 0.3810 & & 0.110 & 0.007 \\
\hline Population Density & & 0.3002 & & 0.278 & 0.036 \\
\hline Regional Attractions & & 0.2999 & & 0.547 & 0.003 \\
\hline Adj. $R^{2}=0.772$ & F-test $=23.831$ & $\mathrm{~N}=28$ & & & \\
\hline
\end{tabular}

Note: $\mathrm{B}=$ Unstandardized Regression Coefficient; $\mathrm{p}$-value $=$ Level of Significance

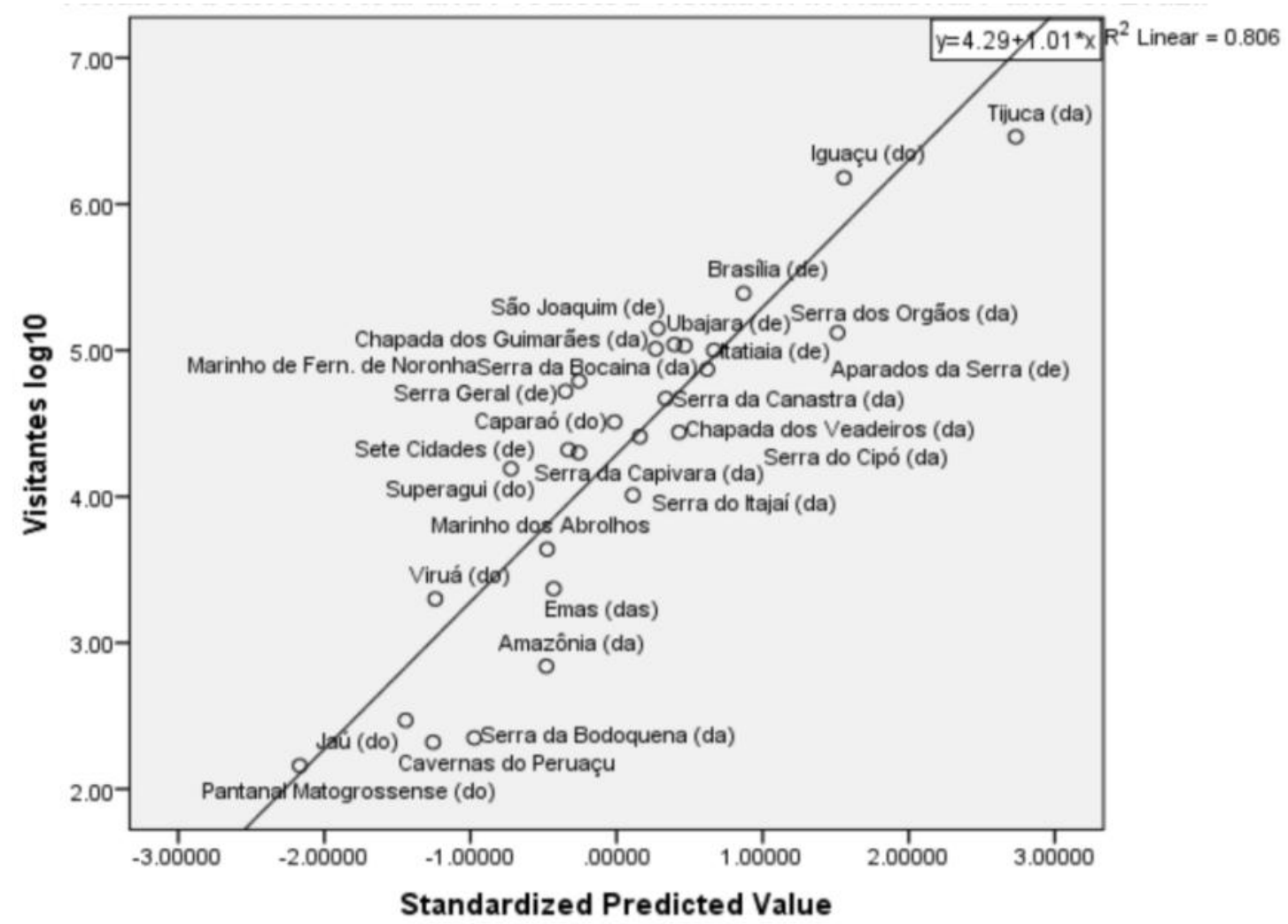

Figure 2: Relation between real and predicted visitation in national parks of Brazil

with access conditions were also included (i.e., distance from large cities and airports). Distances and travel time were estimated with Google Maps.

Data analysis: First, the 13 independent variables were analyzed via Pearson's correlation. Second, only the significant correlated variables $(\mathrm{p}<0.05)$ were included in a stepwise multiple regression analysis. A backward elimination method was employed whereby the deletions of specific input variables were conducted in order to improve the overall model (Cooper \& Schindler, 2011; Zar, 1999). Since the dependent variable did not have a normal distribution, a log transformation was used during the regression analysis. In addition, the following variables were also log transformed: park reputation, regional attractions, hospitality establishments, remoteness, local population, and population density. The assumptions of linearity, independence of errors, homoscedasticity, unusual points, and normality of residuals were also met (Hair, 2010).

\section{RESULTS}

Correlation Analysis: Based on the correlation analysis, 10 out of 13 independent variables established significant relationships with the dependent variable. The three variables that lacked statistical significance were planning tools, land tenure, and local population. Among internal attributes, park reputation and age, diversity of activities, recreation facilities and visitor services were all statistically significant. Essentially, the results demonstrated that higher levels of visitation were the result of natural beauty and the availability of a wide spectrum of recreational opportunities, amenities, and associated services.

Based on the external setting variables, regional attractions, hospitality establishments, population density and remoteness also established significant correlations, which indicated that parks located in established destinations, densely populated regions or 
with easier access receive higher visitation. Finally, the socioeconomic context was also statistically significant since visitation correlated to travel expenditures (see Table 3).

Regression Analysis: Based on the results of the stepwise multiple regression analysis, four variables were identified in the best fit model to predict visitation numbers: 1) park reputation (internal setting - physical attribute), 2) recreation facilities (internal setting managerial attribute), 3) regional attractions (external setting - physical attribute), and population density (external setting - social attribute). Overall, these variables had significant contributions to the model and explained 77 per cent of the variance in visitation numbers $\left(\mathrm{F}=23.831, \mathrm{p}<.0005\right.$, adj. $\left.\mathrm{R}^{2}=0.772\right)($ Table 4).

Among the four variables, park reputation was the strongest predictor with an increase of 1 per cent in reputation resulting in a surge of 0.56 per cent in visitation. Similarly, an addition of one recreation facility in the park infrastructure relates to an increase of 0.11 per cent in visits. Among the external setting variables, regional attractions were also a strong predictor as an addition of 1 per cent in new attractions yields an increase in visits of 0.55 per cent. The other variable, population density, also demonstrated predictive validity as an increase in 1 per cent in density within a buffer zone of $100 \mathrm{~km}$ around the park increases visitation by 0.28 per cent.

In addition, a graphic illustration of the visitation predictions compared with the observed number of visits was formulated. The graph presents a best fit line and shows that the parks were fairly close based on the model. The diagram demonstrates that, at different levels, all parks were sensitive to the chosen variables via the regression analysis. Hence, the model could be a reasonable representation of tourism attractiveness of the national parks in Brazil (see Figure 2).

\section{DISCUSSION}

This exploratory study assessed the relative importance of various internal and external park characteristics in relation to the number of visitors. The variables selected to explain visitation rates were park reputation, recreation facilities, regional attractions, and population density. The results show a similarity with Deng et al. (2002) as they used an expert panel methodology and identified variables such as resources, accessibility, facilities, local community, and peripheral attractions. Despite the different variables used in the model, this study also corresponds with the segmentation categories

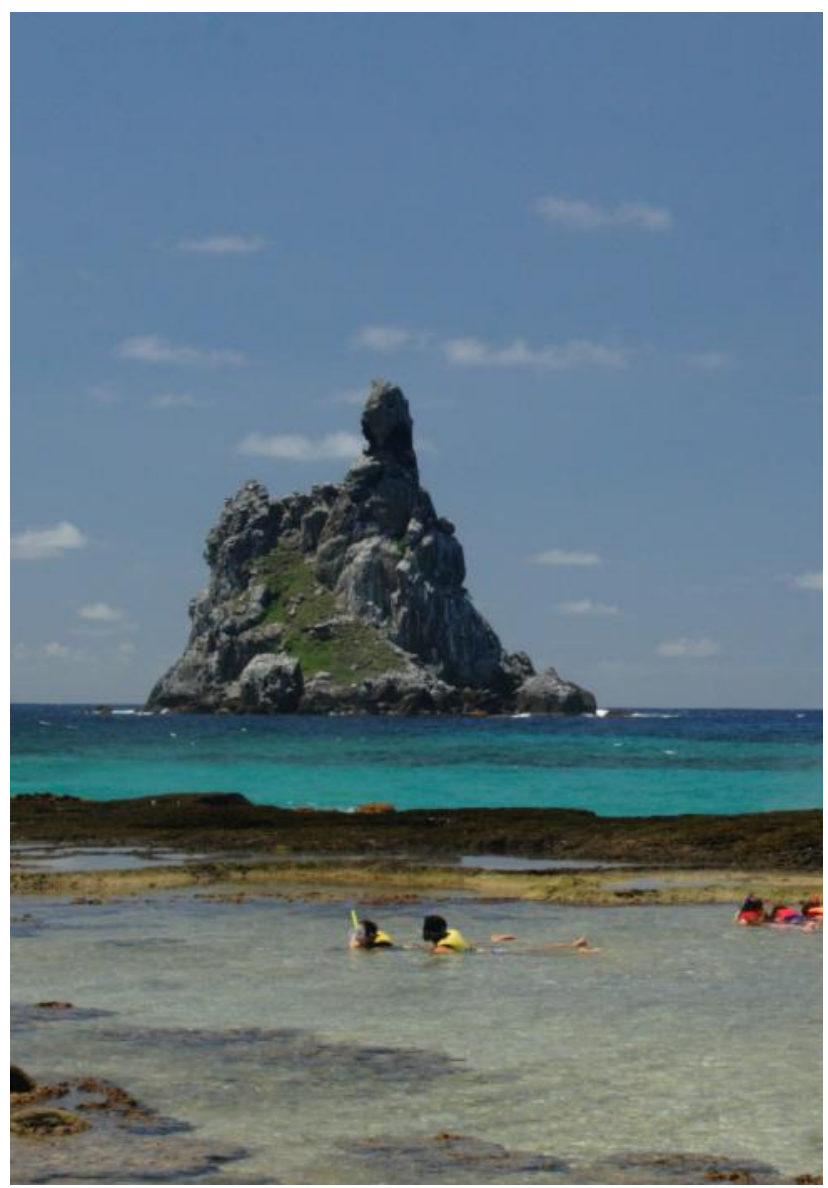

Fernando de Noronha National Park (c) Ernesto V Castro

adopted by Neuvonen et al. (2010). Both models contain variables that represent the natural characteristics, recreation and tourism services, spatial demand, and socioeconomic characteristics of local municipalities.

Results suggested that reputation is a major variable that influences choice for park visitation as well-known areas tend to have higher demands. For example, Tijuca and Iguaçu National Parks are collectively responsible for 74 per cent of all visitation in 2013 (ICMBio, 2014). This is consistent with the findings of several authors (Crouch \& Ritchie, 1999; Lee et al., 2010) that have noted that natural attractions are the primary elements of destination appeal. Given the importance of a park's reputation, which can be propelled by the media, social media, and user-generated content, the results indicate that communication is an important aspect for planning strategies. Park managers need to understand concepts such as destination image and formulate marketing initiatives accordingly to inform their appropriate visitor audience (King et al., 2012).

Two external variables, regional attractions and population density were key predictor variables of visitation. Visitation tends to be higher in higher destination areas with several attractions and within the 
most populated regions of a country. As Deng et al. (2002) found, the relationship between national park visitation rates and the existence of other close attractions demonstrates that the average tourist often visits more than one destination during a given trip. There are two national parks in Brazil that provide a good comparison: Brasilia (Federal District) and Serra da Capivara (State of Piauí). Brasilia, the third most visited national park in 2013 (248,0oo visitors) is located inside the capital city of Brasília which has hundreds of other attractions, while Serra da Capivara receives less than 20,000 visitors per year largely due to its isolated location. Additionally, a substantial number (2.4 million) of city inhabitants of Brasília use the park daily for exercise, including the natural swimming pools and other recreational areas. Conversely, Serra da Capivara is home to 300,000 people that live less than $100 \mathrm{~km}$ from the park.

There was one significant negative correlation with park visits: remoteness. Geographically isolated areas tend to have fewer visitors. This finding is in accordance with other authors who state that accessibility is a critical dimension of a destination (Kim et al., 2003; Lee et al., 2010). Prideaux (2000) highlights the importance of transport infrastructures and offers an example of Cairns in Australia, where the construction of an international airport had led to a rapid growth in tourism. This finding may be an indication that, to improve accessibility to the protected areas, Brazil should invest more in infrastructure. A notable example is the case of Serra da Capivara National Park (see above) where locals have been demanding an airport to be built for years.

Another aspect to be considered in regards to geographically isolated parks (such as Pantanal in the state of Mato Grosso do Sul), or parks requiring access by river (such as Jaú in the state of Amazonas), is that they tend to be visited only by specialized segments, such as birdwatchers. It is also important to consider that the difficulty of access and the expectation of solitude makes some areas more attractive for these specific visitor segments. For these audiences, the number of visitors and accessibility are inversely proportional to the quality of experience (Iatu \& Bulai, 2011). The location of each park should be considered when planning a protected area unit as well as the whole network. It is desirable to have areas, zones and activities designed to offer the widest possible spectrum of recreation opportunities.

The availability of recreational facilities is also a strong factor that influences visitation. For example, visitors tend to prefer more structured parks with visitor centres, boardwalks, and paved internal roads. This result corroborates with findings in other countries (Kim et al., 2003; Neuvonen et al., 2010; Puustinen et al., 2009). Similarly, this is the case for São Joaquim National Park, which has a paved road maintained by the Army for access to a research facility. Although the park has few recreation options, it received more than 139,000 visitors in 2013 largely due to the scenic mountain road. Conversely, Serra do Itajaí National Park (State of Santa Catarina), located in the city of Blumenau (300,000 inhabitants), and very close to the capital of the State, Florianópolis (460,000 inhabitants), registered few visitors in the same year $(10,000)$ due to the lack of facilities.

Brazilian Parks also show a significant positive correlation between the availability of recreation services and the number of visits. This result corroborates with Puustinen et al. (2009) as they found that parks with more recreation services attract additional visitors. In Brazil, with the exception of Fernando de Noronha National Park (State of Pernambuco), an island with strong carrying capacity restrictions, a few parks that have consistent tourism concessionaires are among the most visited (Tijuca, Iguaçu and Serra dos Órgãos). The findings are also comparable with the Finnish parks (Neuvonen et al., 2010) with respect to the positive correlation of visits and diversity of activities. A relevant example in Brazil is Bocaina National Park (State of Rio de Janeiro) which has several different ecosystems (e. g., mountains and beaches) and can offer a wider spectrum of recreation opportunities for different visitor profiles and interests.

While a positive correlation existed between visitors and park age, it was not selected within the model. Despite the fact that several studies have identified a positive influence of park age over demand (Mills \& Westover, 1987; Hanink \& White, 1999; Neuvonen et al., 2010), it is not certain how this variable affects demand. While the most outstanding attractions of a country are primary designated protected areas, older parks have had more time to be structured (e.g., facilities, staff, services) and develop their reputation. Hence, this variable appears to have high correlations with others such as reputation and facilities.

Of note is the land tenure and planning tool variables that did not account for any significant relationships. These variables were included in the scope of the study due to the approach by which some parks have been managed for decades in Brazil. According to the traditional approach, the government acquired all the land and prepared the necessary planning tools prior to outdoor recreation uses. However, these procedures have 


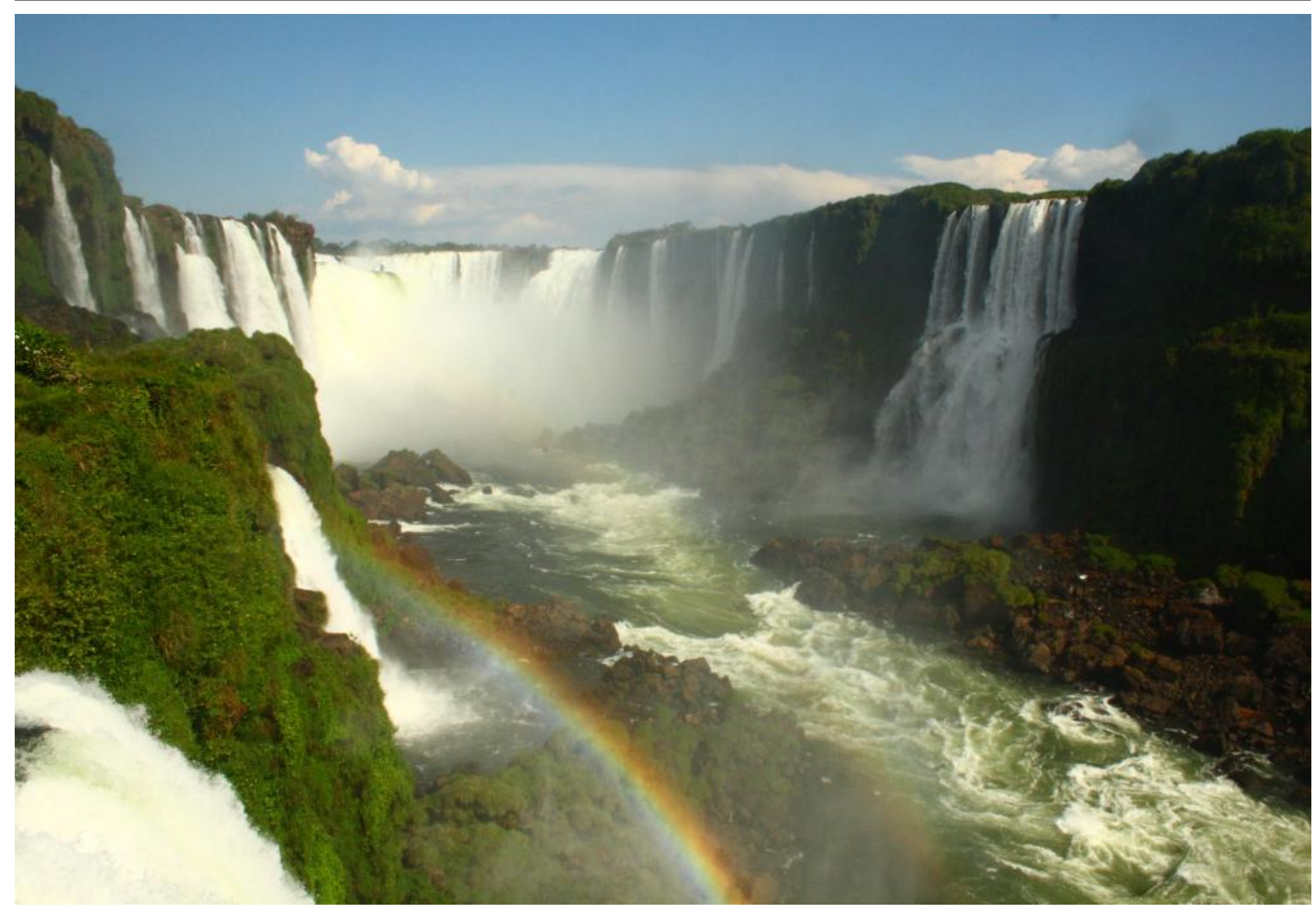

Iguaçu National Park @ Ernesto V Castro

been time consuming as the government has not been able to carry out large scale implementation. In some cases, parks have had unresolved land tenure issues for more than 70 years (e.g., the first Brazilian National Park, Itatiaia - State of Rio de Janeiro, established in 1937). Nevertheless, this issue did not prevent almost 100,000 visitors in 2013. While some parks have outdated general management plans that are more than 30 years old, others do not yet have a plan. This finding may indicate that, despite the debate about the steps needed to fully implement a protected area, public use still occurs in parks with or without land tenure or planning tools. During the protected area creation process, especially for national parks, one of the arguments used to garner support from the residents is the positive economic impacts of tourism (Moisey, 2002). However, what normally happens in Brazil is the prohibition of any public activity following the designation, including pre-existing activities. That positioning has created more opponents than supporters of conservation. São Joaquim National Park (State of Santa Catarina) was created in 1959 and lacks a general management plan, and hence ICMBio officially considers the park not able to host visitors. However, despite the official status, the park has been visited consistently. The results support the view that this strategy, while historically adopted, has been shown to be inefficient.
Moreover, it reinforces the actions taken by ICMBio in recent years to regulate, rather than ban activities in parks (ICMBio, 2012).

\section{CONCLUSION}

The study demonstrated that tourism attractiveness in the national parks of Brazil were correlated to reputation; linked to recreation facilities; and related to attractions in the region and population density. Results show that both internal park attributes and external setting characteristics are considered by visitors. While management and communication policies are important, external factors that are not directly dependent on park agencies also play a part. In this sense, outreach initiatives by managers at the local and regional scales are recommended, as parks are generally considered within the context of an overall destination. Additionally, joint actions with other government agencies and the tourism trade are critical to increase visitor flow to the national parks and adjacent communities.

This model has practical utility and can be used to improve investment efficacy among the parks that already receive visitors, as well as serve to evaluate the tourism attractiveness of new parks. Also, the findings may be useful for communities and small businesses located in the adjacent areas, since adequate prediction 


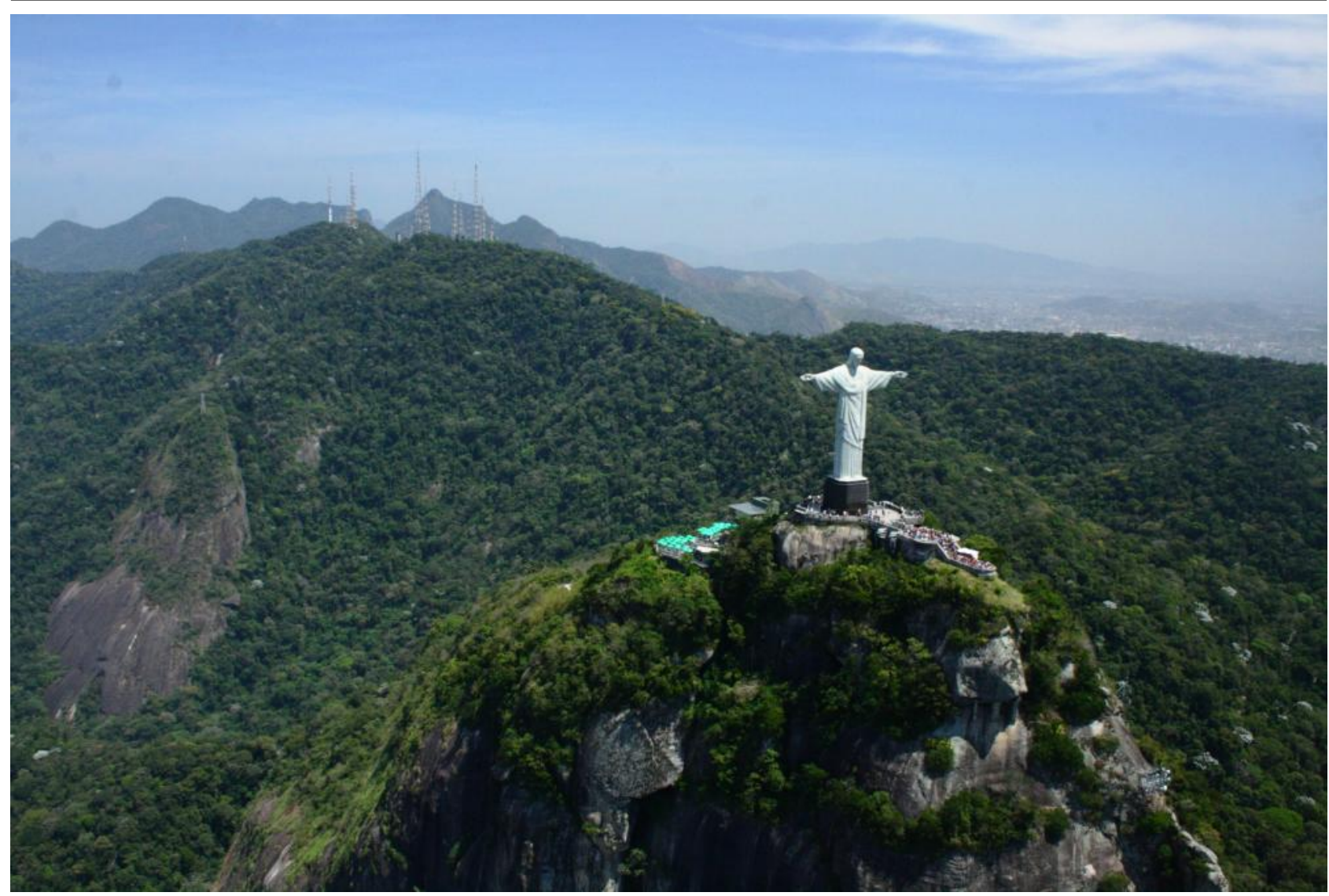

Tijuca National Park (C Ernesto V Castro

of visitor demand provides support for tourism activities. While the sample in this study was small, the analyses provide a platform to further build on this research with respect to the relative importance of different attributes that may attract visitors to the national parks in Brazil. It should also be noted that this study relied on number of visitors as an indicator of performance, which covers just one of the goals of tourism in parks. Quality of visitor experience and satisfaction are other essential elements to increase public awareness of the importance of conservation and raise support for protected areas.

\section{FOOTNOTES}

[1] Data could not be segmented by international and domestic visitors due to the lack of reliable and accurate data collection by ICMBio. However, it was assumed that the majority represented domestic visitors. In addition, a few parks such as Tijuca National Park charge fees for attractions (e.g., Christ the Redeemer) but only count visitors for other locally used areas (e.g., running trails). In such situations, this study incorporated visitor counts regardless of fees paid.

[2] Studies have increasingly utilized the Google search engine as a research tool in various disciplines including tourism (see Mazanec, 2010; Murphy \& Law, 2008).

[3] Official language of Brazil.
[4] User-generated content websites such as TripAdvisor are gaining more credibility from the travelling public and academia (see Ayeh et al., 2013).

\section{ABOUT THE AUTHORS}

Ernesto Viveiros de Castro, M.Sc., is the manager of Tijuca National Park. His academic background is in Conservation Biology. Since 2002, he has worked for the Chico Mendes Institute for Biodiversity Conservation (ICMBio), a government agency responsible for the federal protected areas of Brazil. He was the manager of Serra dos Órgãos National Park and also the National Coordinator of Public Use. He is interested in various aspects of National Park management issues, and how public use can contribute to sensitize people to support protected areas.

Thiago Beraldo Souza works for the Chico Mendes Institute for Biodiversity Conservation (ICMBio), a government agency responsible for the federal protected areas of Brazil since 2002. He was the manager of Pacaas National Park and also worked in the National Coordination of Public Use. Currently, he is on leave pursuing a $\mathrm{PhD}$ in Interdisciplinary Ecology with a focus on Tourism and Recreation Management at the University of Florida, USA. His objective is to understand the relationships between supply, demand and economic benefits of recreation in protected areas. 
Brijesh Thapa, Ph.D., is a Professor in the Department of Tourism, Recreation \& Sport Management at the University of Florida. His research theme is within the nexus of tourism, conservation and sustainability. He has been involved in numerous projects in various capacities in over 32 countries. Additionally, he has been involved in projects at World Heritage Sites with respect to tourism, cultural heritage, and natural resources management issues. Recently, Dr Thapa has focused on numerous capacity building and institutional development projects through curriculum development, research, and training in tourism, nature and cultural heritage conservation, and natural resources management.

\section{REFERENCES}

Ayeh, J. K., Au, N. and Law, R. (2013). Do we believe in TripAdvisor? Examining credibility perceptions and online travelers' attitude toward using user-generated content. Journal of Travel Research, 52(4), 437452. DOI:10.1177/0047287512475217

Clark, R. and Stankey, G. (1979). The Recreation Opportunity Spectrum: A Framework for Planning, Management, and Research. U.S. Department of Agriculture - Forest Service Research paper PNW-98. USDA Forest Service.

Cooper, D. R. \& Schindler, P. S. (2011). Business research methods. New York: McGraw-Hill/Irwin series.

Crouch, G. I. and Ritchie, J. R. B. (1999). Tourism, competitiveness, and societal prosperity. Journal of Business Research, 44(3), 137-152. DOI:10.1016/S01482963(97)00196-3

Deng, J., King, B. and Bauer, T. (2002). Evaluating natural attractions for tourism. Annals of Tourism Research, 29(2), 422-438.

Eagles, P. and McCool, S. (2002). Tourism in National Parks and Protected Areas: Planning and Management. Wallingford, UK: CABI.

Emerton, L., Bishop, J. and Thomas, L. (2006). Sustainable financing of protected areas: A global review of challenges and options. Gland, Switzerland: IUCN.

Gearing, C. E., Swart, W. W. and Var, T. (1974). Establishing a measure of touristic attractiveness. Journal of Travel Research, 12(4), 1-8. DOI: 10.1177/004728757401200401

Hair, J. F. (2010). Multivariate data analysis. Upper Saddle River, NJ: Prentice Hall.

Hanink, D.M. and White, K. (1999). Distance effects in the demand for wildland recreational services: The case of national parks in the U.S. Environment \& Planning, 31(3), 477-492. DOI: 10.1068/a310477

Hu,Y. and Ritchie, J.R.B. (1993). Measuring destination attractiveness: A contextual approach. Journal of Travel Research, 32(2), 25-34. DOI: $10.1177 / 004728759303200204$

latu, C. and Bulai, M. (2011). New approach in evaluating tourism attractiveness in the region of Moldavia (Romania). International Journal of Energy and Environment, 2(5), 165-174.

ICMBio. (2012). Relatório de Gestão de 2011 [Trans. Administrative Report 2011]. Brasília: Chico Mendes Institute for Biodiversity Conservation.
ICMBio (2014). Visitor Numbers in Protected Areas. General Coordination of Public Use and Business CGEUP (internal document), Brasilia.

Kim, S.S., Lee, C. K. and Klenosky, D. B. (2003). The influence of push and pull factors at Korean national parks. Tourism Management, 24(2), 169-180. DOI:10.1016/S0261-5177 (02)00059-6

King, L., McCool, S., Fredman, P. and Halpenny, E. (2012). Protected area branding strategies to increase stewardship among park constituencies. PARKS, 18(2), 5564. DOI:10.2305/IUCN.CH.2012.PARKS-18-2.LMK.en

Laws, E. (1995). Tourism destination management: Issues, analysis, and policies. New York: Routledge.

Lee, C., Huang, H. and Yeh, H. (2010). Developing an evaluation model for destination attractiveness: Sustainable forest recreation tourism in Taiwan. Journal of Sustainable Tourism, 18(6), 811-828. DOI: 10.1080/09669581003690478

Manning, R. E. (2011). Studies in Outdoor Recreation: search and research for satisfaction. $3^{\text {rd }}$ Edition. Corvallis, OR:

Mazanec, J. A. (2010). Tourism-receiving countries in connotative google space. Journal of Travel Research, 49 (4), 501-512. DOI:10.1177/0047287509349269

Mills, A. S. and Westover, T. N. (1987). Structural differentiation. Annals of Tourism Research, 14(4), 486498.

Moisey, R. N., (2002). The Economics of Tourism in National Parks and Protected Areas. In: P. F. J. Eagles and S. McCool, Tourism in national parks and protected areas: planning and management, pp. 235-253. New York: CABI Publishing.

Mulholland, G. and Eagles, P. (2002). African parks: combining fiscal and ecological sustainability. PARKS, 12(1), 42-49.

Murphy, J. and Law, R. (2008). Google scholar visibility and tourism journals. Annals of Tourism Research, 35(4), 10781082.

Neuvonen, M., Pouta, E., Puustinen, J. and Sievänen, T. (2010). Visits to national parks: Effects of park characteristics and spatial demand. Journal for Nature Conservation, 18(3), 224-229. http://dx.doi.org/ doi:10.1016/j.jnc.2009.10.003

Prideaux, B. (2000). The role of the transport system in destination development. Tourism Management, 21(1), 53-63. http://dx.doi.org/10.1016/S0261-5177(99)00079-5

Puustinen, J., Pouta, E., Neuvonen, M. and Sievaenen, T. (2009). Visits to national parks and the provision of natural and man-made recreation and tourism resources. Journal of Ecotourism, 8(1), 18-31. DOI: $10.1080 / 14724040802283210$

Thapa, B. (2013). Introduction to the Special Issue - Managing protected areas: Global perspectives, Volume 1. Journal of Park and Recreation Administration, 31(2), 1-5.

Thapa, B., Parent, G., Mupeta, P. and Child, B. (2011). Zambia Tourism Demand Assessment. Washington, DC: US Millennium Challenge Corporation and US Department of Agriculture-Foreign Agricultural Service.

Weiler, B., Moore, S. and Moyle, B. (2013). Building and sustaining support for national parks in the 21st century: why and how to save the national park experience from extinction. Journal of Park and Recreation Administration, 31(2), 115-131.

Wood, S., Guerry, A., Silver, J. and Lacayo, M. (2013). Using social media to quantify nature-based tourism and recreation. Scientific Reports, 3, 2976. DOI:10.1038/ srep02976 


\section{RESUMEN}

La comprensión de los factores determinantes que afectan el atractivo turístico de los parques nacionales es un instrumento de planificación estratégica para las áreas protegidas. Este estudio exploratorio evaluó la importancia relativa de las diversas características internas y externas de los parques en función del número de visitas en Brasil. Se recolectó información de varias fuentes: administradores de 28 parques, documentos internos de los parques, bases de datos gubernamentales y diversos sitios web. El estudio utilizó análisis de correlación y regresión. Los resultados demostraron que el atractivo turístico en los parques nacionales se puede predecir a través de la reputación, las instalaciones de esparcimiento, lugares de interés en la región y densidad de población. Los resultados revelan que los visitantes consideran tanto los atributos internos del parque como las características externas del entorno. Los resultados tienen utilidad práctica y pueden ser utilizados para mejorar la eficacia de las inversiones entre los parques que ya reciben visitantes, así como para evaluar el atractivo turístico para nuevos parques. Los resultados también son útiles para las comunidades y las pequeñas empresas ubicadas en las zonas adyacentes, habida cuenta de que la predicción adecuada de la demanda de visitantes proporciona apoyo a las actividades turísticas.

\section{RÉSUMÉ}

Comprendre les attributs déterminants qui affectent l'attractivité touristique des parcs nationaux est déterminant pour la planification stratégique des aires protégées. Cette étude exploratoire a évalué l'importance de divers éléments internes et externes aux parcs au Brésil sur le nombre de visites. Des données ont été recueillies à partir de plusieurs sources: 28 gestionnaires de parc, des documents internes au parc, des bases de données gouvernementales et divers sites Web. L'étude est basée sur une analyse de corrélation et de régression. Les résultats ont démontré que l'attrait touristique des parcs nationaux dépendait de facteurs liés à la réputation, aux équipements récréatifs, aux infrastructures de la région et à la densité de la population. Les résultats montrent que les visiteurs prennent en compte les attributs internes et externes aux parcs. Ces résultats présentent un réel intérêt pratique susceptible non seulement d'améliorer l'efficacité des investissements dans les parcs qui reçoivent déjà des visiteurs, mais aussi de servir à évaluer l'attrait touristique de nouveaux parcs. De plus, les conclusions sont utiles pour les communautés et les petites entreprises situées dans les régions adjacentes, puisque une prédiction adéquate de la demande touristique constitue un soutien aux activités de tourisme. 